\title{
Do Real Depreciations Reduce the Income Gap between the Rich and the Poor?
}

\author{
Guangjun $\mathrm{Qu}^{1}$ \\ ${ }^{1}$ Department of Political Science, Economics, and Sociology, Birmingham-Southern College, Birmingham, \\ U.S.A
}

Correspondence: Guangjun Qu, 900 Arkadelphia Road, Box 549007, Birmingham-Southern College, Birmingham, AL 35254, USA. Tel: 1-205-226-7746. E-mail: gqu@ bsc.edu

Received: December 1, 2016

Accepted: January 9, $2017 \quad$ Online Published: February 20, 2017

doi:10.5539/ijef.v9n3p266

URL: https://doi.org/10.5539/ijef.v9n3p266

\begin{abstract}
This study concentrates on the effect of real depreciations of a currency on one key aspect of economic development, the distribution of income. Based upon the recent availability of a real depreciation index and two databases on Gini coefficients, we investigate how real depreciations affect levels and changes in the distribution of income. The panel evidence of more than 158 countries indicates that real depreciations are associated with a decline in levels of income gap between the rich and the poor. They, however, have no statistically significant association with changes in the distribution of income. Therefore, the relationship between real depreciations and levels of the distribution of income is likely to stem from reverse causality. Our main findings may help policymakers who attempt to use a currency depreciation policy fully realize that the policy at least does not hurt the poor.
\end{abstract}

Keywords: real depreciation, income distribution, reserve causality

\section{Introduction}

Although most recent empirical studies have shown that a real depreciation is able to foster long-run growth, there is no such thing as a free lunch in the world (Note 1). In practice, Cooper (1971) reports that in the majority of the 24 cases he analyzed, the finance minister who had engineered the depreciation had been ousted from office 18 months later (Note 2). Presumably, such dismissals arise from discontent of a majority or of a politically powerful minority. Such discontent might arise even if average growth is positive. This suggests again the existence of potential negative effects of a currency depreciation policy. Since about four decades ago, in fact, economists have studied the theoretical possibility that a real depreciation may result in a reduction of total output, increased unemployment, or deterioration of the income distribution (Note 3).

However, most previous studies focus on a nominal depreciation, rather than a real one. The distinction matters for both theorists and policymakers. From theorists' perspectives, a nominal depreciation only measures how much the nominal exchange rate, defined as the unit of a foreign currency per domestic one, declines relative to its previous level. The nominal depreciation fails to show the deviation from its equilibrium level, which is exactly what a real depreciation can measure. According to the "Washington Consensus", an economy may justify a nominal depreciation of its currency as a behavior of moving back to its equilibrium level, but a real depreciation implies a persistent deviation from its equilibrium level, which can be viewed as a strong signal of macroeconomic disequilibrium (Williamson, 1990). Meantime, from policymakers' perspectives, although a nominal depreciation is an important policy tool to achieve a real depreciation in the long term, other policy tools, such as fiscal and income policies, are also able to lead to a real depreciation (Note 4). Consequently, in both theoretical and policymaking senses, studies on potentially negative influences of a real depreciation can complement the literature on the relationship between real exchange rates and development planning and strategies.

This study concentrates on the effect of real depreciations on one key aspect of economic development, the distribution of income. That is, do real depreciations make the rich richer and the poor poorer? This issue became approachable recently because of the availability of one index, the depreciation index advanced in Rodrik (2008), and two datasets on Gini coefficients, the updated version (3.3c) of the World Income Inequality Database (WIID) and the Standardized World Income Inequality Database (SWIID) constructed by UN-WIDER (2008) 
and Solt (2016), respectively. Following the traditional literature on income inequality, we first consider the effect of real depreciations on levels of income inequality. We find that real depreciations are associated with a decline in levels of income inequality of a country.

However, such a relationship may suffer from serious problems of reverse causality given the fact that the distribution of income is persistent in many countries (so current levels of income inequality are highly correlated with past levels). To address this concern, we then examine the relationship between real depreciations and year-to-year changes in income inequality. Our panel evidence of 158 countries indicates that the above mentioned relationship between real depreciations and levels of income inequality appears to stem from reverse causality as real depreciations do not have a significant influence on changes in income inequality.

Although the literature will be reviewed in detail below in Section 2, here it is worth pointing out that this study is distinct from the previous ones in the following respects.

First, as mentioned above, we emphasize possibly negative effects caused by the deviation of real exchange rates from their equilibrium levels (real depreciations), instead of their period-to-period fluctuations (nominal depreciations) which are main interests of previous studies. Making use of the depreciation index advanced by Rodrik (2008), we can examine how a country's macroeconomic disequilibrium, gauged by the index, affects its distribution of income.

Second, due to the lack of data, in particular statistics on the distribution of income across countries, the existing empirical literature mainly considers the relationship between (nominal) depreciations and proxies for the income distribution, such as real wages, labor's share in GDP and employment (Note 4). In contrast, to eliminate concerns as to how well those proxies are able to represent income inequalities, this study employs Gini coefficients, a widely accepted indicator measuring the distribution of income in a country. Owing to the limitation of data, introducing Gini coefficients to a panel analysis is almost impossible until the WIID and the SWIID recently become available. The two databases facilitate our panel analysis by providing more comparable and continuous data of Gini coefficients both across countries and over time.

Third, in terms of estimation methods, most empirical studies on income inequality use cross-sectional estimation technique whereas we choose panel estimation in this paper to control for differences in time-invariant, unobservable country characteristics. Furthermore, with respect to policy implications, even though we find a statistically significant relationship between real depreciations and income inequality across countries, it is still unclear whether the same relationship holds over time within a country. Panel techniques, however, can specifically estimate how a change in real depreciations is associated with a change in a country's income inequality.

To summarize, this study addresses each of these three aspects discussed above and examines the distributional effects of real depreciations based upon the availability of the new depreciation index, the new databases of Gini coefficients, and panel techniques. The study may help policymakers who attempt to use a depreciation policy as part of a policy package to stabilize their economies fully realize that a real depreciation will not hurt the distribution of income. Meanwhile, our findings indicate that the deterioration of income inequality is not a potential explanation as to why policymakers in developing countries usually prefer highly distorted policy tools, such as tariffs and import quotas, to a depreciation policy.

The remaining part of this paper is organized as follows. Section 2 reviews the literature empirically investigating how real exchange rates affect the income distribution. Section 3 describes our econometric methodology and the measures of income inequality employed in our study. Section 4 presents empirical results and Section 5 concludes.

\section{Literature Review}

The traditional theory implies that the impact of a real depreciation on the income distribution differs depending on circumstances. In the short run, a real depreciation policy raises the price of tradables relative to that of nontradables and, hence, increases profitability of the tradable sector. Both labor and owners of capital in this sector benefit from the rapid development of the tradable sector. Their counterparts in the nontradable sector, however, are worse off because the increase in the price of tradables enhances the overall price level if one assumes that real wage and capital returns are sticky in the short term. In the medium term, free labor movement ensures wage rates to be equalized across sectors for the same type of labor. As a result, the distributional effect of real depreciations for a specific type of labor depends upon individual consumption patterns: households with a high propensity to consume imports and tradables lose relative to those with a low propensity. In the long run, such an effect relies on the factor intensity of the tradable sector: labor will win if the production of tradables is 
more labor intensive, while owners of capital will gain if the production of tradables is capital intensive (Note 5).

Compared to the theoretical development, the empirical investigation of distributional effects of real depreciations is relatively scanty. Edwards (1989b) uses data for the 39 devaluation episodes from 29 developing countries to analyze the relationship between devaluations and real wages, a proxy for the distribution of income as he claims. He chooses three types of wages: non-agricultural wages, manufacturing wages and agricultural wages, and compares changes in these wages between three years before the devaluation and three years after the devaluation. Although he acknowledges that his conclusion is very preliminary due to the limitation of the data and the methodology, his finding suggests that real wages exhibited an important increase in the year prior to the devaluation and decreases in the years following the devaluation (Note 6). Edwards also investigates the evolution of labor's share in GDP as another proxy for the income distribution. The test results indicate that there were no significant changes in income distribution in the period surrounding devaluations, which differs from the conclusion he draws according to the data on real wages (Note 7).

Compared to a study using regression analysis, the obvious limitation of Edwards' methodology is that it concentrates on the behavior of the key variables "before" and "after" the devaluation without taking into account the possible role of other polices or external events. In other words, there might be some other factors that raised or lowered real wages during the period of devaluations, especially since devaluations often occur during macroeconomic crises. The limitation, however, can be mitigated once we collect appropriate data and employs regression analysis with control variables.

Galindo et al. (2007) look at the effects of real depreciations on industrial employment. Using a panel dataset on industrial employment and trade for nine Latin American countries, they conclude that real depreciations impact employment growth positively in countries with high trade openness (Note 8).

However, Galindo et al. (2007) shares the same deficiency with Edwards (1989b), namely that real wages or labor shares in GDP or employment are not direct proxies for the income distribution or inequality. One may raise a concern about how well these proxies are able to represent the income distribution across the total population, sectors or countries. Take real wages as an example. As Minot (1998) points out, in most developing countries, wage data refer to the urban formal sector and do not necessarily reflect the standard of living of the poor in the urban informal sector and in rural areas. Moreover, even though the relationship between real depreciations and real wages or employment is as claimed by the authors, it cannot offer any insight on how real depreciations influence the income distribution of a country as a whole. The reason is that these studies focus on returns to labor (real wage) but ignore returns on capital. In fact, at least in the short term when capital is not free to move across sectors, real depreciations are able to raise temporarily returns to capital in the tradable sector relative to those in the nontradable sector. As a result, although real depreciations lead to a rise in real wages, it is likely to occur that income inequality of a country becomes worse as returns on capital rise faster than real wages do.

In contrast to these indirect proxies, the Gini coefficient is a direct measure of income inequality which is the most widespread one due to the availability of its data both across countries and over time. One of the Gini coefficient's main advantages is to demonstrate how income has changed across the whole population, covering wage earners, capital owners, and all others. Another advantage of the Gini coefficient is that it can be simply compared across countries since it is a ratio whereas other measures, such as wages or per capita income, are usually expressed by local currencies. Further, Clarke (1995) finds that the Gini coefficient is highly correlated with other measures of income inequality. Along with these strengths, however, one weakness of the Gini coefficient is that the same value of the Gini coefficient may represent more than one Lorenz curve. Thus, a trivial change in the Gini coefficient might not necessarily indicate the same trivial change in income inequality. But this problem is not unique to the use of the Gini coefficient (Note 9).

Bahmani-Oskooee (1997) is thus far the only empirical study using Gini coefficients to consider the relationship between (nominal) depreciations and income inequality. Based on a cross-country sample of 24 observations, he finds that nominal depreciations are correlated to a rise in income inequality. It is evident that any conclusions derived from a sample of 24 observations might not be generalized. The lack of data on Gini coefficients is the main reason that other authors used proxies of income inequality, such as real wages or labor shares in GDP or employment. Besides the scarcity of sample observations, another flaw in Bahmani-Oskooee (1997) is from the cross-country regression technique he uses. As discussed in the introduction, cross-country estimators can be severely biased by omitted variables. In addition, as far as policymaking decisions, the cross-country results are not informative since it fails to address the issue of how a change in real devaluations within a given country affects a change in that country's income inequality. 
Last, as discussed in the introduction, note that all above the studies look at the relationship between (nominal) depreciations and income inequality. In other words, these authors ascribe changes in inequality to period-to-period fluctuations of exchange rates, instead of macroeconomic disequilibrium gauged by the deviation of real exchange rates from their equilibrium levels.

\section{Methodology and Data}

\subsection{Real Depreciations and Levels of Income Inequality}

Following the literature on income inequality, we first consider the level of income inequality, i.e. the level of the Gini coefficient, as a dependent variable to test the effects of a real depreciation on the income distribution (Note 10). Based on the Kuznets' hypothesis and other existing empirical work, we choose initial per capita income, growth rates of GDP per capita, and population growth as explanatory variables, besides our depreciation index (Note 11). Hence, the econometric specification takes the form:

$$
I_{i t}=\alpha_{0}+\alpha_{1} \ln (\overline{\text { real depreciations }})+\alpha_{2} \ln \left(y_{i, t-1}\right)+\alpha_{3}\left[\ln \left(y_{i, t-1}\right)\right]^{2}+\alpha_{4} g_{i t}+\alpha_{5} p_{i t}+\varepsilon_{i t}
$$

where $I_{i t}$ is the Gini coefficient, $\mathrm{y}_{i, t-1}$ is the initial per capita income, $g_{i t}$ is the growth rate of GDP per capita, and $p_{i t}$ is population growth for country $i$ at year $t$. Given that a higher value of the depreciation index suggests the more a country tends to keep its real exchange rate below its equilibrium level, a real depreciation will be positively associated with an increase in income inequality if $\alpha_{l}$ is positive. The theoretical studies mentioned in previous sections lead to an ambiguity of the sign of $\alpha_{1}$, depending upon how a real depreciation moves productive resources between the tradable and nontradable sectors and how returns are distributed within each sector.

Moreover, as a robustness check, we also replace the Gini coefficient with income shares of the top and bottom quantile to investigate how a real depreciation affects income of the two extreme groups. All results of the robustness check are reported in the appendix.

\subsection{Real Depreciations and Changes in Income Inequality}

Although using the level of Gini coefficients as a dependent variable is the most common in the literature, the econometric specification, like equation [1], may suffer from serious problems of endogeneity or reverse causality.

Suppose $\alpha_{1}$ in equation [1] is found to be statistically significant. Does that mean that a real depreciation could affect the level of income inequality so that an economy could alter the distribution of income by changing its real exchange rate? Or does that merely mean that income inequality partially causes an economy to choose a specific level of real exchange rates in which case a policy that affects a real depreciation will not then lead to any change in the degree of income inequality. The occurrence of the latter scenario, in fact, is highly possible, as shown by Cooper (1971). If an economy is polarized and the rich minority is politically powerful, they have many incentives to prevent real depreciation. For instance, if the revenue of the rich minority is mainly from exports of natural resources or primary products, a real depreciation will lead to a permanent decline in their revenue. Moreover, if the rich has a higher propensity to consume imports than the poor does, a real depreciation will constrain the consumption of imports of the rich more than that of the poor. Under these circumstances, owing to its own benefits, the rich and powerful minority will prefer an appreciation policy to a depreciation one. The causality, hereby, likely runs in the opposite direction, that is, from income inequality to a real depreciation (or an appreciation).

These possibilities are quite relevant to this analysis since the literature has shown that the income distribution is determined by many fundamental factors and is relatively stable for many countries (Note 12). Therefore, equation [1] might not be good at showing the distributional effects of real depreciations as current levels of income inequality are highly correlated with past levels. Taking this into account, we also use year-to-year changes in the Gini coefficient as a dependent variable in the following alternative specification.

$$
\Delta I_{i t}=\alpha_{0}+\alpha_{1} \ln (\overline{\text { real depreciations }})+\alpha_{2} \ln \left(y_{i, t-1}\right)+\alpha_{3} p_{i t}+\varepsilon_{i t}
$$

where the dependent variable is the difference of Gini coefficients between year $t$ and $t-1$. In this regard, our specification more closely follows that of Edwards (1997), Savvides (1998) and Sylwester (2002, 2003). These studies use the changes in the level of income inequality as the dependent variable when examining how trade policies or education expenditures influence the distribution of income.

Obviously, a disadvantage of using the change in income inequality is that we will lose some observations because we need two consecutive years' values of income inequality to calculate one difference. This problem 
will not be intractable if the data of Gini coefficients are continuous over time for most countries. However, Gini coefficients were reported once every five or ten years before the 1990s, especially in developing countries, resulting in the loss of many observations. Given that the information on income inequality is already scarce, this is an important reason why most previous studies either use the level of Gini coefficients or present cross-sectional evidence, instead of panel evidence. This is also the reason why we still consider equation [1] where the level of Gini coefficients is the dependent variable, even with the above mentioned problems. However, one dataset which is recently available enables us to use changes in Gini coefficients under the framework of panel-data analysis without losing too much information.

\subsection{Data}

The data on Gini coefficients and population growth are from the World Development Indicators (WDI) 2016. The data on nominal exchange rates, purchasing power parity conversion factors, income per capita, and annual growth in GDP per capita are collected from the Penn World Tables (PWT) Version 8.0.

However, most of the data on Gini coefficients from the WDI are discontinuous over time. We have 794 observations across 158 countries when using the level of Gini coefficients as a dependent variable, but both numbers decline dramatically when switching to the change in Gini coefficients as a dependent variable. The sample comprises only 252 observations across 48 countries, including 78 observations from 21 developing countries. Apparently, the WDI dataset does not allow us to derive any reliable conclusions from the regressions with the change in Gini coefficients as a dependent variable.

Recently, following the methodology of Deininger and Squire (1996), the World Institute for Development Economics Research of the U.N. University (UN-WIDER) made their updated version (3.3c) of the World Income Inequality Database (WIID) accessible to the public. The WIID 3.3c is the most comprehensive dataset of income inequality statistics, providing a total of 6,854 observations across 179 countries. Although special efforts are made so as to maximize the comparability of the data both across countries and over time, the data still contain a large variety of income definitions, area and population coverage, reference units, and sources of surveys. The most common combination includes only 738 observations across 95 countries and, hence, loses the majority of the information in the original dataset (Note 14).

Solt (2016) creates the Standardized World Income Inequality Database (SWIID) to better deal with the trade-off problem between comparability and coverage in the WIID. A custom missing-data algorithm was employed to standardize the WIID. The SWIID only reports two comparable Gini indices, based on gross and net income, from 176 countries for as many years as possible from 1960 to present. The SWIID is particularly suited to our study as it enhances the comparability and continuity of Gini coefficient data both across countries and over time without a substantial loss of coverage. Accordingly, in our empirical tests discussed below, we use the SWIID as a parallel dataset of the WDI to examine the relationship between real depreciation and income inequality.

\section{Empirical Results}

\subsection{Real Depreciations and Levels of Income Inequality}

Table 1 presents regression results based on a sample of all countries and one of just developing countries, respectively. As previously discussed, we introduce the quadratic term of the initial income only when the levels of Gini coefficients are dependent variables so as to account for a possible Kuznets' curve.

Obviously, real depreciations are correlated with a decrease in levels of income inequality of a country since the coefficients on the depreciation index are negative no matter what samples are used. These coefficients are almost all statistically significant at the 1-percent level, except the one with the Gini coefficient of net income as a dependent variable in the sample of all countries. As discussed in the last section, identifying causality from these results is problematic since a country with a relatively unequal distribution of income might exert more effort to prevent real depreciations than their counterparts with a relatively equal distribution of income.

In addition, the coefficients on control variables display the following implications. First, the positive sign on the initial income together with the negative sign on the quadratic term of the initial income are supportive of the Kuznets' hypothesis in the sample of all countries. But the same inverted-U shape is not shown in the sample of developing countries. Second, population growth is a statistically significant factor correlating to a higher Gini coefficient. 
Table 1. Real depreciations and levels of income inequality

\begin{tabular}{|c|c|c|c|c|c|c|}
\hline \multirow[b]{2}{*}{ Independent variables } & \multicolumn{3}{|c|}{ All countries } & \multicolumn{3}{|c|}{ Developing countries } \\
\hline & $\mathrm{GINI}_{1}$ & $\mathrm{GINI}_{2}$ & $\mathrm{GINI}_{3}$ & $\mathrm{GINI}_{1}$ & $\mathrm{GINI}_{2}$ & $\mathrm{GINI}_{3}$ \\
\hline \multirow[t]{2}{*}{ Depreciation } & $-4.25^{* * *}$ & $-2.31^{* * *}$ & -0.500 & $-4.61^{* * *}$ & $-1.61^{* * *}$ & $-2.26^{* * *}$ \\
\hline & $(-4.57)$ & $(-5.59)$ & $(-1.26)$ & $(-3.39)$ & $(-2.56)$ & $(-3.68)$ \\
\hline \multirow[t]{2}{*}{ ln initial income per capita } & $65.74^{* * *}$ & $23.34^{* * *}$ & $41.93^{* * *}$ & -10.56 & $32.82^{* * *}$ & $20.48^{* *}$ \\
\hline & $(9.25)$ & $(9.23)$ & $(17.18)$ & $(-0.426)$ & $(3.09)$ & $(1.97)$ \\
\hline \multirow[t]{2}{*}{$\left(\right.$ ln initial income per capita) ${ }^{2}$} & $-3.82^{* * *}$ & $-1.40^{* * *}$ & $-2.62^{* * *}$ & 1.01 & $-2.06^{* * *}$ & $-1.24^{*}$ \\
\hline & $(-9.01)$ & $(-9.48)$ & $(-18.32)$ & $(0.632)$ & $(-3.00)$ & $(-1.84)$ \\
\hline \multirow[t]{2}{*}{ Growth of real GDP per capita } & 0.017 & $-0.072^{* * *}$ & $-0.111^{* * *}$ & 0.078 & $-0.095^{* * *}$ & $-0.114^{* * *}$ \\
\hline & $(0.252)$ & $(-2.63)$ & $(-4.20)$ & $(0.877)$ & $(-2.58)$ & $(-3.17)$ \\
\hline \multirow[t]{2}{*}{ Population growth } & $4.25^{* * *}$ & $2.11^{* * *}$ & $2.74^{* * *}$ & $2.27^{* * *}$ & $1.51^{* * *}$ & $1.50^{* * *}$ \\
\hline & $(12.37)$ & $(16.12)$ & (21.64) & $(4.43)$ & $(7.92)$ & $(8.00)$ \\
\hline No. of observations & 794 & 2917 & 2962 & 249 & 1260 & 1290 \\
\hline No. of countries included & 158 & 143 & 143 & 74 & 90 & 90 \\
\hline
\end{tabular}

Note. Here $\mathrm{GINI}_{1}, \mathrm{GINI}_{2}$, and $\mathrm{GINI}_{3}$ are dependent variables. GINI is the data of Gini coefficients obtained from the WDI; GINI ${ }_{2}$ is the data of Gini coefficients obtained from the SWIID and calculated based on gross income; $\mathrm{GINI}_{3}$ is the data of Gini coefficients obtained from the SWIID and calculated based on net income.

\subsection{Real Depreciations and Changes in Income Inequality}

As mentioned in previous sections, the discontinuity of the WDI data on Gini coefficients results in a large loss of sample observations. When using the WDI data, only 252 observations from 48 countries are available for the sample of all countries and 78 observations from 21 countries for the sample of developing countries (see columns 1 and 4 in Table 2). On the basis of these small samples, we find that real depreciations are negatively correlated to changes in inequality and that such relationships are statistically significant at the 10-percent level in both samples. Again, we remind readers to consider the reliability of these results with caution.

Focusing on the results based on the SWIID data, problems with small sample estimation disappear since we obtain more than 1,100 observations from 78 developing countries. Three out of four real depreciation coefficients are negative but all of them are statistically insignificant. That means that real depreciations do not have a significant impact on changes in the distribution of income and, hence, the negative and statistically significant coefficients on real depreciations reported in Table 1 are likely to convey reverse causality. With a view of policymaking considerations, these insignificant coefficients may be good news for developing countries (about to) pursuing a real depreciation policy as there is no evidence that doing so will lead to the deterioration of income inequality for a country as a whole. Furthermore, population growth may lower changes in inequality and the initial level of income has no effect on changes in inequality.

Table 2. Real depreciations and changes in income inequality

\begin{tabular}{|c|c|c|c|c|c|c|}
\hline \multirow[b]{2}{*}{ Independent variables } & \multicolumn{3}{|c|}{ All countries } & \multicolumn{3}{|c|}{ Developing countries } \\
\hline & $\Delta \mathrm{GINI}_{1}$ & $\Delta \mathrm{GINI}_{2}$ & $\Delta \mathrm{GINI}_{3}$ & $\Delta \mathrm{GINI}_{1}$ & $\Delta \mathrm{GINI}_{2}$ & $\Delta \mathrm{GINI}_{3}$ \\
\hline \multirow[t]{2}{*}{ Depreciation } & $-0.917^{*}$ & -0.067 & 0.016 & $-3.00^{*}$ & -0.026 & -0.037 \\
\hline & $(-1.68)$ & $(-0.903)$ & $(0.280)$ & $(-1.80)$ & $(-0.191)$ & $(-0.338)$ \\
\hline \multirow[t]{2}{*}{ In initial income per capita } & -14.14 & -0.056 & 0.040 & -53.29 & 0.034 & 0.087 \\
\hline & $(-1.43)$ & $(-1.55)$ & $(1.45)$ & $(-0.630)$ & $(0.363)$ & $(1.14)$ \\
\hline \multirow[t]{2}{*}{ Population growth } & -0.187 & $-0.127^{* * *}$ & $-0.088^{* * *}$ & -0.274 & $-0.135^{* * *}$ & $-0.093^{* * *}$ \\
\hline & $(-0.922)$ & $(-4.72)$ & $(-4.29)$ & $(-0.593)$ & $(-3.19)$ & $(-2.70)$ \\
\hline No. of observations & 252 & 2670 & 2715 & 78 & 1111 & 1141 \\
\hline No. of countries included & 48 & 136 & 136 & 21 & 78 & 78 \\
\hline
\end{tabular}

Note. Here $\Delta \mathrm{GINI}_{1}, \Delta \mathrm{GINI}_{2}$, and $\Delta \mathrm{GINI}_{3}$ are dependent variables. $\Delta \mathrm{GINI}_{1}$ is calculated based on the data of Gini coefficients obtained from the WDI; $\Delta \mathrm{GINI}_{2}$ is calculated based on the data of Gini coefficients of gross income obtained from the SWIID; $\Delta \mathrm{GINI}_{3}$ is calculated based on the data of Gini coefficients of net income obtained from the SWIID.

\section{Concluding Remarks}

We examine the distributional effects of real depreciations based upon the availability of the new depreciation 
index, the new databases of Gini coefficients, and panel-data estimation techniques. Our main findings are the following. First, real depreciations are associated with a decrease in income inequality, but such an association appears to be dominated by reverse causality since countries with high initial inequalities, such as Latin American economies, prefer a real appreciation policy whereas countries with low initial inequalities, such as East Asian economies, prefer a real depreciation policy. Second, real depreciations have no significant effects on changes in income inequality at the 5-percent level, implying that an increase in inequality is not a subsequent consequence of pursuing a real depreciation policy.

Although this study contributes to the literature by investigating how real depreciations affect income inequality of a country as a whole, specific channels through which such impacts can be realized are still mysterious. For example, in the short run, are the effects of real depreciations upon wage rates and returns on capital distinct across the tradable and nontradable sectors? In the medium run, are the effects of real depreciations upon consumption distinct across consumers with different propensities to consume? In the long run, are the effects of real depreciations upon income inequality distinct across countries with different factor endowments? Along with the availability of more databases, relevant empirical examinations should be conducted in the future.

\section{References}

Ahluwalia, M. S. (1976). Inequality, poverty, and development. Journal of Development Economics, 3, 307-342. https://doi.org/10.1016/0304-3878(76)90027-4

Bahmani-Oskooee, M. (1997). Effects of devaluation on income distribution. Applied Economic Letters, 4, 321-323. https://doi.org/10.1080/758532601

Bahmani-Oskooee, M., \& Miteza, I. (2002). Do nominal devaluations lead to real devaluations in LDCs? Economics Letters, 74, 385-391. https://doi.org/10.1016/s0165-1765(01)00575-4

Blecker, R., \& Razmi, A. (2008). The fallacy of composition and contractionary devaluations: Output effects of real exchange rate shocks in semi-industrialised countries. Cambridge Journal of Economics, 32, 83-109. https://doi.org/10.1093/cje/bem021

Bruno, M. (1978). Exchange rates, import costs, and wage-price dynamics. Journal of Political Economy, 86, 379-403. https://doi.org/10.1086/260678

Clarke, G. (1995). More evidence on income distribution and growth. Journal of Development Economics, 47, 403-427. https://doi.org/10.1016/0304-3878(94)00069-o

Cline, W. (1975). Distribution and development: A survey of literature. Journal of Development Economics, 1, 359-400. https://doi.org/10.1016/0304-3878(75)90019-x

Cooper, R. (1971). Currency depreciation in developing countries. Princeton Essays in International Finance, 86. https://doi.org/10.7202/1003830ar

Deininger, K., \& Squire, L. (1996). A new data set measuring income inequality. World Bank Economic Review, 10(3), 565-591. https://doi.org/10.1093/wber/10.3.565

Diaz-Alejandro, C. (1965). Exchange rate devaluation in a semi-industrialized country. The MIT Press.

Easterly, W. (2007). Inequality does cause underdevelopment: Insights from a new instrument. Journal of Development Economics, 84, 755-776. https://doi.org/10.1016/j.jdeveco.2006.11.002

Edwards, S. (1986). Are devaluations contractionary? Review of Economics and Statistics, 501-508. https://doi.org/10.2307/1926028

Edwards, S. (1988). Real and monetary determinants of real exchange rate behavior: Theory and evidence from developing countries. Journal of Development Economics, 29(3), 311-341. https://doi.org/10.1016/0304-3878(88)90048-x

Edwards, S. (1989a). Exchange controls, devaluations and real exchange rates: The Latin American experience. Economic Development and Cultural Change, 37(3), 457-494. https://doi.org/10.1086/451738

Edwards, S. (1989b). Real exchange rates, devaluation, and adjustment: Exchange rate policy in developing countries. The MIT Press.

Edwards, S. (1997). Trade policy, growth, and income distribution. American Economic Review, 87, 205- 210.

Gala, P. (2008). Real exchange rate levels and economic development: Theoretical analysis and econometric evidence. Cambridge Journal of Economics, 32, 273-288. https://doi.org/10.1093/cje/bem042

Galindo, A., Izquierdo, A., \& Montero, J. (2007). Real exchange rates, dollarization and industrial employment 
in Latin America. Emerging Markets Review, 8(4), 284-298. https://doi.org/10.1016/j.ememar.2006.11.002

Johnson, O., \& Salope, J. (1980). Distributional aspects of stabilization programs in development countries. IMF Staff Papers, 27, 1-23. https://doi.org/10.2307/3866860

Krugman, P., \& Taylor, L. (1978). Contractionary effects of devaluations. Journal of International Economics, 445-456. https://doi.org/10.1016/0022-1996(78)90007-7

Kuznets, S. (1955). Economic growth and income inequality. American Economic Review, 45, 1-28.

Larrain, F., \& Sachs, J. (1986). Contractionary devaluation, and dynamic adjustment of exports and wages. NBER Working Paper, No. 2078. https://doi.org/10.3386/w2078

Minot, N. (1998). Distributional and nutritional impact of devaluation in Rwanda. Economic Development and Cultural Change, 379-402. https://doi.org/10.1086/452343

Papanek, G., \& Kyn, O. (1986). The effect on income distribution of development, the growth rate and economic strategy. Journal of Development Economics, 23, 55-65. https://doi.org/10.1016/0304-3878(86)90079-9

Rodrik, D. (2008). The real exchange rate and economic growth. Brookings Papers on Economic Activity, 2, 365-412. https://doi.org/10.1353/eca.0.0020

Solt, F. (2016). The standardized world income inequality database. Social Science Quarterly, 97(5), 1267-1281. https://doi.org/10.1111/ssqu.12295

Sylwester, K. (2002). Can education expenditures reduce income inequality? Economics of Education Review, 21, 43-52. https://doi.org/10.1016/s0272-7757(00)00038-8

Sylwester, K. (2003). Changes in income inequality and the black market premium. Applied Economics, 35(4), 403-413. https://doi.org/10.1080/00036840210134530

Twomey, M. (1983). Devaluations and income distribution in Latin America. Southern Economic Journal, 49(3), 804-821. https://doi.org/10.2307/1058718

UNU-WIDER. (2015). World income inequality database, version 3.3c, October 2015. Retrieved from https://www.wider.unu.edu/download/WIID3.3

Williamson, J. (1990). What Washington means by policy reform. In John Williamson (ed.), Latin American Adjustment: How Much Has Happened? Washington, Institute for International Economics.

\section{Notes}

Note 1. See Rodrik (2008) and Gala (2008), for instance, on the growth-enhancing effects of a real depreciation. When we mention "real depreciation", we follow the definition of depreciation introduced by Edwards (1989b): a real depreciation suggests that the actual real exchange rate exceeds the long-term equilibrium rate.

Note 2. Here the word "depreciation" means a nominal depreciation of domestic currency relative to foreign currencies.

Note 3. For example, there are many theoretical and empirical studies on negative effects of a (nominal) depreciation, or devaluation, on total output, namely "contractionary devaluation". See Diaz-Alejandro (1965), Krugman and Taylor (1978), Larrain and Sachs (1986), Edwards (1986, 1989a, 1989b), and Blecker and Razmi (2008).

Note 4. See Bruno (1978), Edwards (1989b), Bahmani-Oskooee and Miteza (2002), Rodrik (2008) among others.

Note 5. See Edwards (1989b), Bahmani-oskooee (1997), and Minot (1998). As Edwards (1989b) points out, for example, "the fact that there have been virtually no systematic cross-country empirical studies of devaluation and its effects on income distribution is in part a reflection of the lack of reliable data on income distribution in these countries" (p. 311).

Note 6. See Diaz-Alejandro (1965), Krugman and Taylor (1978), Johnson and Salope (1980), Larrain and Sachs (1986), and Edwards (1989b).

Note 7. Based on his developing countries' sample, Cooper (1971) also finds that real wages often declined after devaluations. Additionally, Twomey (1983) uses data on nine Latin American economies to draw similar conclusions that devaluations lower real wages and widen the distribution of income.

Note 8. To my knowledge, Edwards' study is the only one on depreciations using labor's share in GDP as a 
proxy for the income distribution. He reminds us that these findings on labor's share in GDP are remarkably inconclusive because, for most countries, labor shares move very slowly through time, making the analysis on the distributional impacts of (real) devaluations rather difficult.

Note 9. Such an effect will be reversed as liability dollarization increases. That is, the overall impact of real depreciations is negative in the industries with high liability dollarization.

Note 10. See Sylwester (2002).

Note 11. Among others, Ahluwalia (1976), Papanek and Kyn (1986), Clarke (1995) and Easterly (2007) use the Gini coefficient as a measure of income inequality to study the relationship between the income distribution and economic development.

Note 12. See Kuznets (1955), Cline (1975), Papanek and Kyn (1986), and Bahmani-Oskooee (1997) for the selection of control variables.

Note 13. See, for example, Edwards (1997) and Sylwester (2002).

Note 14. See Solt (2016) for details.

\section{Appendix 1: Real Depreciations and Income Shares}

To further explore the mechanism through which real depreciations affect the income distribution of a country, we employ what are available in the WDI, the income share of highest 20 percent and lowest 20 percent, to investigate the impact of real depreciations upon income of the two extreme groups in the total population. What are shown in Table 3 are the results based on the sample of all countries. We replace Gini coefficients by the income shares as dependent variables, keeping the same control variables. Interestingly, real depreciations influence the income share of highest 20 percent and the income share of lowest 20 percent in opposite ways: they coincide with a decrease in the former but an increase in the latter. In other words, on average, the rich lose and the poor benefit from a real depreciation policy. Despite the ambiguity of the theoretical background of the empirical results, they do provide a possible explanation why policymakers in developing countries usually prefer to implement highly distorted policy tools, such as tariffs and import quotas, instead of devaluing. If one can suppose that the rich who will suffer from real depreciations has much stronger influence upon political decisions, in particular in developing countries, public policies are likely to be shaped in favor of the rich minority.

Meanwhile, Table 2 reveals the following outcomes. First, the income share of highest 20 percent exhibits an inverted-U shape along with the level of initial income, whereas the income share of lowest 20 percent exhibits an upright-U shape. Second, the rich benefits from population growth, while the poor loses.

Table 3. Panel regressions of the income share on real depreciations

\begin{tabular}{lcc}
\hline Independent variables & Income Share of Highest 20\% & Income Share of Lowest 20\% \\
\hline Depreciation & $-3.24^{* * * *}$ & $1.21^{* * *}$ \\
& $(-4.31)$ & $(5.54)$ \\
In initial income per capita & $52.42^{* * * *}$ & $-14.10^{* * * *}$ \\
& $(9.21)$ & $(-8.53)$ \\
(ln initial income per capita) ${ }^{2}$ & $-3.04^{* * * *}$ & $0.815^{* * *}$ \\
& $(-8.97)$ & $(8.27)$ \\
Population growth & $3.54^{* * *}$ & $-0.836^{* * * *}$ \\
& $(12.96)$ & $(-10.55)$ \\
\hline
\end{tabular}

\section{Copyrights}

Copyright for this article is retained by the author(s), with first publication rights granted to the journal.

This is an open-access article distributed under the terms and conditions of the Creative Commons Attribution license (http://creativecommons.org/licenses/by/4.0/). 